\title{
The Heroine Concept in a Filipino Graphic Narrative
}

\author{
Estrella T. Arroyo \\ College of Liberal Arts \\ University of Saint Anthony \\ Philippines \\ stararroyo.dean@yahoo.com
}

Citation: Arroyo, E. T. (2021). The heroine concept in a Filipino graphic narrative. Notion: Journal of Linguistics, Literature, and Culture, Vol 3(1), p. 1-10. http://doi.org/notion.v3i1.3870

\begin{tabular}{|c|c|}
\hline Article Info & ABSTRACT \\
\hline $\begin{array}{l}\text { Article History } \\
\text { - Article Received } \\
18^{\text {th }} \text { March } 2021 \\
\text { - Article Accepted } \\
12^{\text {th }} \text { April } 2021\end{array}$ & $\begin{array}{l}\text { This study explored the concept of "HEROINE" in the context of "Darna," a } \\
\text { Filipino graphic narrative written by Mars Ravelo that was first published on May } \\
\text { 13, } 1950 \text { by Filipino Komiks. Extracted from the } 27 \text { episodes of "Darna" are realities } \\
\text { of experience as well as innuendos related to the real character of Darna, the super } \\
\text { heroine. Further, the study delved into a deeper meaning of heroine beyond its } \\
\text { lexical meaning. As a result, the researcher formulated her own definition of } \\
\text { "HEROINE" as "Humaneness and Equanimity in Reimagining Optimistic, Iconic, } \\
\text { Novel, and Empowered" persona, which led to the findings that, indeed, Darna has } \\
\text { reached her apotheosis as a superheroine. These insights were not fathomed had it } \\
\text { not been for the researcher's focus on close reading, application of Expressive } \\
\text { Realism, and "Argustic" reading. Keen eyes are needed to enjoy reading a graphic } \\
\text { narrative which is both visual and verbal. The study proved that in Philippine society, } \\
\text { Darna is the most accepted, loved and idolized Filipino icon as savior of a devastated } \\
\text { and crippled society after World War II. Lastly, it is aimed that this humble analysis } \\
\text { will put itself into the realm of a body of Pop Literature and the Humanities. }\end{array}$ \\
\hline
\end{tabular}




\section{INTRODUCTION}

Stories are the frameworks of our consciousness and storytelling forges links among people, between people, and ideas. To make sense of our world and to keep our culture alive, we write and tell stories. Narratives are carriers of knowledge in a social group that may transfer them in a context' sensitive way. Further, narratives allow readers to capture attitudes, perceptions, and connections that are hardly expressed. According to Marcus Jenal[19] in his article, "Five reasons why using narrative is important for understanding social change," narratives are central in how we, humans, organize our society. Weaving life-lessons into stories that get repeated helps us to learn how to behave and become accepted members of a society (Jenal.n.d).

Graphic narrative, an example of a unique literary genre, calls a reader's attention visually and spatially to the act, process, and duration of interpretation. Because of these features, a graphic narrative is an autographic form that offers an intricately layered narrative language - the language of comics that comprises the verbal, the visual, and the way these two representational modes interact on a page[10].

Today's most enduring graphic narratives took shape - serious, imaginative works that explore social and political realities by stretching the boundaries of a historically mass medium. Graphic narrative offers compelling, diverse examples that engage with different styles, methods, and modes that fit into the realities of experience. This literary genre has echoed and expanded on the formal inventions of fiction, from modernist social and authentic attitudes and practices to the postmethod shift toward the democracy of popular forms.

The comics' (graphic narrative) most important icon, the panels, are a general indicator that time or space are divided. McCloud[21] says "Comics panels fracture both time and space, offering a jagged, staccato rhythm of unconnected moments." The empty space, called the gutter, plays host to what is the very heart of comics and that what is between the panels is the element of comics that is not duplicated in any other medium. The comics is assembled as a way of carving out a tradition, in a rich history of forms that leads to a contemporary excitement.

In America, comics was invented in 1895. In the 1950s, 1960s, and 1970s, comics reflected the seismic cultural shifts, often produced by war. As historical enunciation weaves jaggedly through paradoxical spaces and shifting temporalities, comics as a form that relies on space to represent time, becomes structurally equipped to challenge dominant modes of storytelling[13].

In Indonesia, comics does not figure popularly in the world history of global comics because of the lack of translations. Some Indonesian comics have drawn a bit of attention and international awards. They also have contributed the drawing and coloring of comics published by DC Comics and Marvel Comics. In general; however, comic book readers around the globe remain blind to the unique and rich character of Indonesian comics, maybe due to the integrated elements of Indonesian comics that make it difficult; in terms of quality, for them to compete with the comics from other countries[15].

In the Philippines, the production of Filipino graphic narratives or Komiks are proliferating in various forms from the Tagalog poetry and prose to Literary Studies and other contemporary writings. Filipino narratives have been into quests influenced by time and milieu revealing what is in the consciousness of the Filipinos. With the introduction of many literary genres in the country, one is openly embraced by Filipinos - the Komiks.

In 1929, the first Komiks was created through "Kenkoy" by the young Antonio Velasquez who collaborated with Romualdo Ramos. In the 1930s, several publications followed. The Komiks was perceived as important source of entertainment for the readers. In the 1950s to 1970s, Komiks was a phenomenal success when readers started to adjust to a different dimension of reading. It was written in a simple way but draws the emotions of the reader. The style of the writing is linear in design and bewildering in frame[23]. In the middle of the proliferation of the Komiks in the Philippines, "Darna" came into existence. 
"Darna" unfolds realities that reveal the Filipino image and character. It features the stories told in the right moment, where the context resembles the situation when the story happened. Over time, the people know which stories to use at what point of time to convey a particular message. The messages are transmitted through gestures and glances, through conversations or monologues, or narration done by the writer. Each instance is based on subtleties that can only be interpreted by translating into descriptive words that manifest insights from equally subtle relationships. All these stories originated in concrete experiences that make use of powerful actions and language. Darna was a foil to all these men; she was a champion; she was a woman. According to Larry Sipin, of the Manila Times; as quoted by Reyes[24]:

Darna as a cultural icon was born at a time when the Philippines was struggling to come out of the devastation of World War II. She served as a salve to a country looking for champions.

In the process, the researcher embarked on close reading of the texts through the lens of Expressive Realism. This is a theory that literature reflects the reality of experience as it is perceived by one individual who expresses it in a discourse which enables other individuals to recognize it as true[17]. Expressive Realism[16] means reality as expressed by the author[9]. It is a fusion of Aristotle's concept of art as "mimesis" with the Romantic concept of art as expressing the perceptions and emotions of a person "possessed of more than unusual organic sensibility”[12].

Further, Expressive Realism shows how characters' value-laden commitments are articulated in concepts enacted in concrete situations and juxtaposed alongside opposing commitments. Expressive realist mediates affective attachments of readers to characters' commitments through techniques that facilitate critical analysis. This study seeks to promote critical reflection and affective attitudes.

In this study, Social Action Theory, as one of its anchors, traces and interprets the connection of Darna, the character, and the society she came from and the society she vowed to protect. The theory emphasizes the role of the active individual and interactions between and among people in shaping her personal identity. Human action needs emphatic understanding of the motives why there are changes to the social structure. Acting out social roles is quite demanding especially in power-structure of society to the process of identity construction.

Max Weber emphasized both "Social Action Theory" as structural and action approaches necessary in developing full understanding of society and social change[6]. He argued that empathetic understanding is crucial to understanding human action; generalizations about basic types of motivation for human action can be made, and that structure shape human action. Darna, the empowered heroine, assumed social responsibility in her being a "savior image" evident in her encounters with characters or phenomena that attempted to destroy mankind.

The present study finds itself significant by contributing invaluable insight on how a graphic narrative shall be read. Through this study, the narrative shall be taken differently by the readers because the gap between reality and fiction shall be bridged, leading to a more comprehensive appreciation and reading of the Filipino narrative because of Literary Criticism's contextual application. Moreover, Darna Komiks was elevated to a higher view because this narrative gives a prophetic indication that "Darna" narrative was created to symbolize the present Philippines. Thus, the solution to the challenges is found in the in-depth analysis and evaluation of "Darna." The komiks reflect the status quo of the society and struggles that have long been in the process of resolution.

In addition, this research contributes to the study on popular literature, which scholars have not emphasized due to scarcity of resources and references in terms of scholarly work in Darna narrative. With this, the researcher opened the door for future engagements on Darna Komiks as a subject for discussion to further dig up the aspects of this field.

Lastly, this study provides an innovative way of reading a text in a multidisciplinary way of understanding the world through the narrative. This challenges the researcher, educators, and scholars to 
explore practical ways of employing reading as an engaging task that is exciting, yet relevant.

To see the world from a holistic perspective, one has to consider breaking the big picture into bits and pieces and looking at things from a more specific perspective. Borrowing the concept of Nick Joaquin's "Heritage of Smallness," this study is a microcosm of Philippine society. What we see in the bigger lenses shall be understood in the microscopic view that ordinary people can express. The reality of experience that is defined by the raw experience of "Darna" is a portrayal of what comes around. If reality and fantasy are patched together, a sociocultural understanding is grasped; thus, this study attains unprecedented results.

The study is a document analysis of Mars Ravelo's 27 episodes of Darna stories in graphic narrative written in Filipino language in the 1950s. Close reading through the lens of Expressive Realism in relation to Social Action Theory are the main vehicles in unfolding the realities of experience, especially the exploration of the Heroine concept in the Philippine context[4].

Lent[20] discussed the history of comics in the Philippines in detail and provided an overview of the writers', scholars', and readers' perspective. Darna was also mentioned as Mars Ravelo's that was described as a barrio girl with supernatural powers. This was analyzed by a scholar as a fantasy komiks that rectify nature's neglect and contemporary society's lack of concern by empowering the crippled, the ugly, the sickly, and the poverty-stricken with marvelous gift ranging from a magical typewriter, ballpoint pen, or winnowing basket, to more standard folk amulet[24]. This discussion on the historical development of Komiks in the Philippines provided an overview for the researcher to trace back the origins, the development, downfall, challenges, and rise of the Komiks industry as well as writers present in those era.

Fernandez[18] opened the conversation of what lies ahead of the Popular Culture and what are the lapses that needs to be filled. She also mentioned the things that should be researched on that most scholars missed to find. This is an important material for the researcher to contribute new knowledge in the field of popular culture.

All of those studies greatly contributed to the researcher's in-depth analysis of the graphic narratives in finding answers to the study's problem: What is the "heroine Concept" in "Darna"?

\section{METHODOLOGY}

This chapter includes the research design, methods and procedure, and Ethical Considerations. It also provides the process of analysis of the data, using close reading, Expressive Realism, and "Argustic reading" to be able to extract the Heroine concept in "Darna."

\section{a. Research Design}

This study is a Qualitative Research Method which refers to the process of collecting data in a constructivist perspective or advocacy participants' perspectives[14]. In this study which analyzes a Filipino graphic narrative in a form of "Komiks," an exploratory research design shall be used to expound the researcher's study that will help uncover the significant information to achieve new insights on the concept being achieved and hereby develop hypothesis for the future researches[22].

Through this, the study would be utilizing the close reading of the Komiks to unveil the Expressive Realism in the Filipino Narrative - "Darna" through "Argustic reading". This is the theory that reflects the reality of experience as perceived by an individual and expresses it in discourse and enable other individual to recognize it as true. (Expressive Realism, n.d.) It will further the reflection of the social action theory that focuses on the interaction of an individual and the people.

\section{b. Method and Procedures}

The researcher was able to collect the 27 Darna Komiks by Mars Ravelo from an online blogger who compiled all of them. The Komiks started with episodes about Narda, Darna, and Valentina. This Komiks was read and analyzed by the researcher through close reading. These Komiks were printed for accessibility and ease in analysis. 


\section{c. Document Analysis}

The 27 Darna Komiks by Mars Ravelo will be used as the main material of the research. Expressive realism, pertains to the reality of experience that the audience perceive and enables the individual to recognize the truth[11]. Reality[9] has been seen in various levels such as reality in experience, behavior, and in the text. Through the expressive realism, the researcher will extract the apotheosis in Darna by looking closely into the dialogues, images, plot, and characteristics of the Komiks.

\section{d. Ethical Consideration}

The research focuses on document analysis and does not include any biological human subject. Document analysis in this context include the 27 Darna Komiks by Mars Ravelo that focuses on Darna and Valentina as the main characters in the Komiks.

The Komiks were downloaded from a blog posted by Video 48 on November 25, 2008 referred by Simon Santos, a blogger who is interested in Darna Komiks. The researcher emailed Simon Santos to request for the link to take hold of the reference for the study. The Darna Komiks, from 1st episode to the 27th episode, are available for public consumption since it was posted publicly.

\section{RESULT AND DISCUSSION}

This chapter presents the analysis and interpretation of the graphic narrative through close reading, Expressive realism, and "Argustic reading".

\section{a. Concept of Heroine}

Darna is a superheroine created by Mars Ravelo that has brought a turn in the graphic narrative, leaving an impactful effect on the readers. The dissemination of this graphic narrative increased the readership and semiotically implanted a lingering effect on Filipino sociocultural identity and consciousness. With this, Darna becomes more than just a woman, Darna is perceived as a superheroine.

The heroine is defined as a woman admired or idealized for her courage and outstanding achievements or noble qualities (Heroine, 2021). This is the standard definition yet, too general to associate with Darna. So, the researcher articulated her new perspective of Darna as a H.E.R.O.I.N.E. that is defined as "Humaneness and Equanimity in Reimagining an Optimistic, Iconic, Novel, and Empowered" persona.

Each of the letters in the "HEROINE" represents a word that solidifies the researcher's claim that Darna is and will always be a HEROINE.

\section{b. Humaneness}

This is a personality that is marked with sympathy, compassion, consideration for humans or for animals. A known Filipino proverb would always say that "madali maging tao, mabirap magpakatao" (It is easy to be human but it is difficult to be humane). Humaneness is character, cultured from within and influenced by the social circle but controlled by an individual integrity. A person who has humaneness has a philanthropist's heart that is pro-human and exists for others because one knows how to sympathize with others (Humaneness, 2021).

Darna's humaneness is very much evident due to her good heart. She bravely faced the "Kapre" despite her inferiority in size. And fought the Kapre to end the destruction in the place. Darna did an appropriate action because she saw the people and society in chaos. She bravely stood up on her role for the society to end the impediments to the peace that they have in their village. Such humaneness is engraved in her heart.

Darna, though powerful, still did not put the law in her own hands and gave Valentina, her nemesis, a chance to correct her mistake by paving respect to the law and encouraged Valentina to face the consequences of her action. She may be powerful but she is a superhero who thinks not of herself but of humanity. Darna's good heart is naturally seen in her actions. No amount of revenge was shown by Darna because she saw Valentina not as an enemy but as a human.

Humaneness in Darna's heroine characteristics are supported by her portrayal as a heroine who should stand in the midst of the destruction to defend people against the odds. But, her being a heroine does not denote dominance over the rule of law. Lastly, Darna does not choose the people to help but her heart is good for everyone who deserves it. 
This popular literature graphic narrative revealed a very important figure in reflecting societal contemporary issues. In Philippine settings, people always look for a savior image with humaneness and these concepts were brought to the present era of thinking. The need to have a leader who can stand up on behalf of the minority is a leader who has the humaneness ingrained in her character.

\section{c. Equanimity}

Equanimity is defined standardly as a calm state of mind and attitude to life so that one would never lose his/her temper or become upset[3]. Imperfection in terms of attitude is most likely missing in some superheroes for they have weaknesses portrayed in times of situational confrontation when they are pushed to their limits. However, Darna's personality was created with shaped character and with clear personality and equanimity. Darna is depicted as a heroine in a disposition with balance in facing big or small circumstances whether for the benefit of either male or female and of rich or poor capacity.

To be of right balance in terms of personality is societally upright but not everyone is able to abide due to human limitations and frailties. Through the Komiks, Darna has been projected as a woman with equanimity for she is not biased for her own recognition but for the sake of those who are in need.

Every person in authority should have an equanimity because, like Darna the graphic narrative, a society should have purposeful balance in decision making, planning session, and management of the different responsibilities.

\section{d. Reimagining}

The structured society is a product of the colonization of the western countries that have visited the Philippines and organized even the most basic system in the country. It started the smallest heritage and influenced the consciousness of people in the country in terms of leadership, gender, identity, and perspective. But, Darna broke these established realities in the society and portrayed an image that allowed reimagining from what is existing.

Reimagining the perspectives and presenting a redefined thinking of gender role happened because of Darna and Valentina's dominance in the society. Two strong women who redefined the gender role of Filipina are confined in domestic chores but the two persons broke the silence and become the savior and evil that are supreme in the society. This leads to rethinking of the role of men and the capability of other gender in the society.

This reimagining also spreads to the identity of the people in terms of the hierarchy of the leaders. Instead of leading the society, they become followers of the dominant being.

This may be gleaned as a parallel situation in the contemporary times when the "Gabriela," a women's group in the Philippines, redefined the role of women in the society by proposing supplemental law that would defend women against violence of men. This now reinvents the image of women in society as more functional and equal to the rights that they deserve as men.

\section{e. Optimistic}

Positivity often gets blurred when not so good situations surround. Yet, consistent grasp that there is hope should always be a must. This view is significant in creating an influence to what and who surrounds. Optimism, in the context of Darna Komiks, is a confident and heroic attitude because it looks forward to winning against the odds.

Darna's optimism was evident in the entire graphic narrative that she even volunteered herself to fight for the country's peace and order knowing that she could defeat the evilness in the society.

The view of optimism that despite the fear and negative situations, the pursuit to freedom on oppression and misdemeanor uplifts. This scenario may metaphorically pertain to the old woman in the Philippines. The woman who is in fear, because of the various threats, confronts the situation by looking for someone and leads in bringing hope for a better perception. As equally experienced by the country at the time of writing, devastation was elsewhere and conflicts were also evident; yet, the presence of optimism that Darna portrayed was always being hoped for. 


\section{f. Iconic}

A person who is distinguished as iconic is never doubted in identity because of the perceived characteristics. Furthermore, the dictionary defined the iconic person as widely known and wellacknowledged especially for distinctive excellence in many ways[5]. This iconic identity is radiated by Darna with a total change in physical, psychological, moral, and social being.

Her iconic power denotes a combined maleness and femaleness that allowed her to perform well as a woman empowered for all seasons. A true iconic personality is one that has no vested interest in it and does not do things to bring recognition to one's self. Darna has been an iconic identity in the graphic narrative that is philanthropic in nature and made to serve the needs of others over the self and the family.

Darna is an icon who does not savor popularity but engages with the problem and joins with the solution in combating the crimes and human rights. An icon participates to achieve the solution in societal problems. To be an icon is to establish an identity such in the line, "si Darna, ang marilag na mambabakang krimen at kampeon ng katarungan?' Darna is not just a superhero and a savior but an activist who defends the rights that people deserve. Thus, maintaining peace and order in the society. When people unite their desire to achieve their communal goal, the iconic image of Darna is even more uplifted.

A person who is an icon does not have any bias in her personality and it is but natural for an iconic being like Darna to be of good heart for everyone that creates a ripple of empowerment to people who witness and experience her actions.

In the contemporary era, Filipino adapted the subscription to the iconic image where their homes are being poured out. Filipinos always search for a person whom they would look up to and become an inspiration to continue living. Such an inculcation in the Filipino consciousness that an icon is one of the motivating factors of Filipinos to have a glimpse of hope.

\section{g. Novel}

To be novel is to be original that has recently come to existence[8]. This may pertain to an experience that has never been the same as before. In the context of the graphic narrative - Darna, her novelty in terms of ability, power, motivation, and accountability has brought a surprise to her family and society.

This is the first story in Philippine popular literature that a magic stone could transform a cripple girl to become a full woman of beauty and strength.

The novelty that is traced back from the very reason why she was given the chance to be a superheroine is because of the goodness of her heart with selfless dedication for the innocents and to vanquish evil.

\section{h. Empowerment}

True empowerment comes when one converts intention into action and when one is making positive decisions based on what one wants. This empowerment is the true essence of being a figure that Darna possesses. She is a champion and a woman for all seasons who undeniably reflects the inner voices of the women in the society.

The ability of Darna to fly is a symbol for empowerment. Her ability to do so is a strength and a power. This is a representation of freedom and power in the dark days of the 1950s. With Darna in the graphic narrative, the landscape for power and a body for reality is interpreted and a woman filled with empowerment is attained.

De Vera quoted Capili on his Reading of Darna in Popular Filipino Culture that superheroes (such as Darna) blur the line between fantasy and reality, but they help sustain what many aspire or hope for. For many Filipinos, having their own superhero allows them to remain optimistic and hopeful despite the many difficulties that they go through. Such empowerment that Darna has gifted the Filipino people - an empowerment that comes from within and an impact that is evidently seen. This fantasy realism expressed in the narrative is aspired and hoped to be evident to win the battles and confront the worldly threat.

\section{i. Apotheosis of Darna}

The operational definition of heroism created an image of deification where Darna becomes the highest order of a woman placed at the pedestal. Her uniqueness and quintessence because of strength, power, advocacy, beauty and most of all, "pinaglalaban 
ang karapatan at pakikibaka na siya lamang ang nakakagawa" (fights and advocates the right for the humanity that she alone can perform.

Darna is seen as a heroine with great cultural significance that has been passed on generation after generation and has been translated in various modes to disseminate the cultural ideology that Darna carries. This now reflects the society and contributes an identity that demystifies the apotheosis characteristics of Darna.

No one can ever match Darna's identity as Philippine heroine that is celebrated even in the 21st century because Darna herself is already a vessel that carries the culture and society and represents the popular culture of the Philippines. She is the Apotheosis of the superheroes in the Philippine komiks, a woman who is more than a superhero but a stimulus for the next generation in rediscovering Filipino identity.

Darna has reached the cultural sublimity in the Philippine humanities and is regarded as the character who reached the sublime. Even at present, Filipino people always look for a Darna figure who would salvage the society from its long death.

\section{j. The Nemesis of Darna}

Nemesis is a person who inflicts vengeance and is characterized by being a formidable rival or opponent of the main character[6]. In the context of graphic narrative, Valentina is the nemesis of Darna in every incarnation and appears to be similar to Medusa. However, in the graphic narrative, Valentina can also control all the snakes and sometimes react on behalf of Valentina and obeys what her mind dictates.

Such is a nemesis that is capitalized on anger and being unmerciful. Valentina's parents complain a lot about the presence of snakes in the house and the stressful environment caused by many troubles. Then, Valentina questioned the love of the parents because of those comments about her and it triggered anger and her merciless killing of her parents. Killing was her choice and violence was the effect.

Further, she announced to all of her minions (snakes) her main goal of killing the entire humanity by gathering all of her allied snakes. Her evilness has become strongly evident since then. Her dominance leaves the weak with no ability to beg off but follow. Everything is achieved at the start because evil was allowed to establish its own ground in the story strongly and wreaks havoc on the people in the society.

Fear and problems are brought to the society because of the desire to be followed and be dominant. However, the more she becomes strong, the more that the story insinuates an age-long theme that evil would not prevail; hence, Valentina is defeated in the last part of the story.

\section{k. Argustic Reading}

This is a reading strategy devised by the researcher in extracting the different views in interpreting the text. The word "argustic" was taken from Argus Panoptes. He is a 100-eyed giant in Greek mythology; the son of Arestor, whose name "Panoptes" meant "the all-seeing one" [1]. The researcher further explains that "Argustic" is her coinage - an adjective that alludes to the 360-degree scope of sight of the reader. A researcher must not limit his/her understanding of meaning to what the naked eye perceives. The vast coverage of the mythical 100 eyes connotes that the more the eyes are, the better the perpectives.

This is a manner of reading a text that is not myopic or hyperopic for there shall be no biased conclusion on the reading for everything shall be considered and interpretation shall be multidimensional. It debunks the mono-perspective of reading such as reading for linguistic development, reading for pleasure, reading for critical analysis. Through "Argustic Reading," all aspects are restored regardless of the reader's purpose of reading because a text is read with objectivity while subjective aspects are also embraced.

In this study, reading of comics during the time it was released, was purposely for entertainment. Then, scholars read the Darna narrative in a specific critical concept. But in a more enriching exploration of ideas, an "Argustic Reading" transcends the analysis to its sublimity producing a more comprehensive exploration of what the text is pertaining to. 
In doing so, the procedure commences in the selection of the narrative to be read. Then, a method of reading the narrative should be identified clearly for guidance. Furthermore, the many perspectives may be explored through various knowledge on the literary theories to be employed. This shall allow the reader to see the significant aspect of the reading. Lastly, linking the findings of the study to the past and present times should be employed to engage with the practical aspects in facing reality.

\section{CONCLUSION}

Through close reading, Expressive realism, and "Argustic reading," the interpretation reveals the concept of heroine in a Filipino graphic narrative as the significant figure in reflecting societal contemporary issues supported by humaneness, a personality that is marked with sympathy, compassion, consideration for humans or for animals. Colonization influenced the consciousness of people in the country in terms of leadership, gender, identity, and perspective. But, Darna, the figure, broke these established realities in the society and portrayed an image that allowed reimagining from what is existing. Further, it can be a new icon, empowerment, and optimistic state of mind in the society.

\section{REFERENCES}

[1] Greek Mythology.com. (2021). Argus Panoptes. Retrieved at 1 March 2021 from https://www.greekmythology.com/Myths/Creat ures/Argus Panoptes/argus panoptes.html

[2] De Vera, R. S. (2020, May 24). Darna: Ageless, allmedia at 70 . Philippine Daily Inquirer. Retrieved from

https://entertainment.inquirer.net/376578/darn a-ageless-all-media-at-70

[3] Collinsdictionary.com. (2021). Equanimity. Retrieved from:

https://www.collinsdictionary.com/dictionary/e nglish/equanimity

[4] Lexico.com. (2021). Heroine. Retrieved from: https://www.lexico.com/en/definition/heroine
[5] Merriam Webster Dictionary. (2021). Iconic. Retrieved from https://www.merriamwebster.com/dictionary/iconic

[6] Thompson, K. (2016, July 13). Social Action Theory-A Summary. ReviseSociology. Retrieved from:

https://revisesociology.com/2016/07/13/social -action-theory-a-summary/

[7] Merriam Webster Dictionary. (2021). Nemesis. Retrieved from https://www.merriamwebster.com/dictionary/nemesis

[8] Dictionary.com. (2021). Novel. (2021). Retrieved from

https://www.dictionary.com/browse/novel

[9] Basic Knowledge 101. (2021). Reality. Retrieved from:

https://www.basicknowledge101.com/subjects/ reality.html\#: : text $=$ Reality $\% 20$ are $\% 20$ the $\% 20 \mathrm{t}$ hings $\% 20$ in,physically $\% 20$ experienced $\% 20$ by $\% 2$ 0the $\% 20$ senses.\&text $=$ Real $\% 20$ is $\% 20$ something $\% 20$ that $\% 20$ should $\% 20$ not $^{\circ} \% 20$ be $\% 20$ taken $\% 20$ lightly

[10] Chute, H. L. \& DeKoven, M. (2006). Introduction: Graphic narrative. MFS Modern Fiction Studies 52(4):767-782. Retrieved from https://muse.jhu.edu/article/209131

[11]Belsey, C. (1980). Critical Practice. New York: Routledge.

[12]Bhattacharyya, K. (2018, August 5). What is expressive realism in simple words? Quora. Retrieved from: https://www.quora.com/Whatis-expressive-realism-in-simple-words

[13]Chute, H. (2008). Comics as literature? Reading graphic narrative. Modern Language Association Vol. 123(2), pp. $452-465$ http://www.jstor.org/stable/25501865

[14]Creswell, J. (2003). Research design: Qualitative, quantitative, and mixed method. California: Sage Publications Inc.

[15]Darmawan, H. (2019). Indonesian Comics in The Map of World Graphic Novel. Indonesia National Book Committee. Retrieved from 
https://islandsofimagination.id/web/articles/in donesian-comics-map-world-graphic-novel

[16]Darmouth.edu. Expressive Realism. Retrieved from

https://www.dartmouth.edu/ engl5vr/third.ht

$\underline{\mathrm{m}}$

[17]Fahad, A. (2017, May 1). Critical Practice by Catherine Belsey: New Criticism. Epic Note. Retrieved from http://epicnotes1.blogspot.com/2017/05/critic al-practice-by-catherine-belsey.html

[18]Fernandez, D. G. (1989). The Philippine Press System: 1811-1989. Quezon City: Ateneo de Manila University.

[19]Jenal, M. (2017, November 7). Five Reasons Why Using Narrative is Important for Understanding Social Change. Retrieved from Marcus Jenal: https://www.jenal.org/five-reasons-why-usingnarrative-is-important-for-understanding-socialchange/

[20]Lent, J. A. (2009). The first one bundred years of philippine komiks and cartoons. Tagaytay City: Yonzon Associates, Inc.

[21]McCloud, S. (1994). Understanding Comics. New York: William Morrow Paperbacks.

[22]Peniel, B. (2015). Research Design. Retrieved from https://www.researchgate.net/publication/3082 62064 Research Design

[23]Reyes, S. S. (2003). Rosario De Gurman Lingat 1924-1997: The Burden of Self and History. Quezon City: Ateneo De University Press.

[24]Reyes, S. S. (2009). The Komiles and Retelling the Lore of the Folk. Quezon City: Ateneo de Manila University. 